\title{
LEGAL REGIME FOR THE PROTECTION OF BANKING CONSUMERS IN NIGERIA: AN OVERVIEW
}

\author{
Salisu Malami \\ Aminu Kano College of Islamic and Legal Studies, \\ B.U.K Road Kano, Nigeria. \\ E-mail: smalamilegal@gmail.com \\ Zuryati Mohamed Yusoff \\ School of Law, UUM COLGIS, Universiti Utara Malaysia \\ E-mail: zuryati@uum.edu.my
}

\begin{abstract}
Bank customers/consumers are the drivers of the banking industry. Their protection should be a priority. This is because consumer protection boosts consumer confidence and enhances banking quality. This may be the reason the Central Bank of Nigeria (CBN) made consumer protection part of its reform policies in the banking industry. This paper examined the legal regime on banking regulation and consumer protection. The banking sector regulatory laws were critically examined. These included the Consumer Protection Council Act, 1992, the Banking Act 1969, and the Central Bank of Nigeria Act 2007, etc. The analysis revealed that the banking laws and the regulatory institutions provide inadequate protection for the banking consumer. This is a cause for concern to the banking consumers in the country. This state of things could be considered as the contributory fact or for growing consumer rights abuses and humiliation in the Nigerian banking industry.
\end{abstract}

Keywords: Consumer abuses, Legal regime, Central Bank, Regulatory, Nigeria.

Abstrak: Pelanggan bank/pengguna merupakan penggerak kepada industri perbankan. Perlindungan kepada mereka sepatutnya menjadi keutamaan. Ini adalah kerana perlindungan kepada pengguna akan menggalakkan keyakinan pengguna dan meningkatkan lagi kualiti perbankan. Perkara ini mungkin menjadi alasan Bank Negara Nigeria menjadikan perlindungan pengguna sebahagian daripada polisi pembaharuannya dalam industri perbankan. Artikel ini mengupas rejim perundangan berkaitan peraturan perbankan dan perlindungan pengguna. Undang-undang perintah sektor perbankan dikaji secara kritikal. Undang-undang 
ini termasuklah Consumer Protection Council Act 1992, Banking Act 1969, Central Bank of Nigeria Act 2007 dan lain-lain. Analisis telah menunjukkan bahawa undang-undang perbankan dan institusi-institusi berkaitan menyediakan perlindungan yang tidak mencukupi kepada pelanggan bank. Ini merupakan sebab utama kepada keprihatinan terhadap pengguna-pengguna perbankan di negara ini. Keadaan ini boleh dianggap sebagai fakta penyumbang kepada peningkatan penyalahgunaan hak-hak pengguna dan penindasan dalam industri perbankan di Nigeria.

Kata kunci: Penindasan pengguna, Rejim undang-undang, Central Bank, Peraturan, Nigeria.

\section{INTRODUCTION}

The financial system (hereinafter referred to as the system) comprises of a wide range of issues from the normal commercial bank services to mortgage financing and other related services such as discount houses. ${ }^{1}$ Like the nervous system is to the human body, the financial system of the banking industry is a part is the nervous system of countries' economies. ${ }^{2}$ While the financial system serves as the nervous system, the banking industry is the nucleus of the financial system. ${ }^{3}$ The system matters most to citizens and the overall economy. ${ }^{4}$

Nigeria, like any country in the world, has a financial system with a banking system that predates the country's independence. Nigeria's

1 Mark E Budnitz. "Arbitration of Disputes Between Consumers and Financial Institutions: A Serious Threat to Consumer Protection." Ohio St. J. on Disp. Resol. 10, 1995, 267; Fischer Black, Merton H Miller, and Richard A Posner. "An Approach to the Regulation of Bank Holding Companies." Journal of Business, 1978, pp 379-412.

2 Sanusi, L. Sanusi. "Banking Reform and its Impact on the Nigerian Economy," CBN Journal of Applied Statistics 2, no. 2, 2012, 115.

3 Oluwagbenga Gideon Olanrewaju, Adeleke Gabriel Aremo, and Aiyegbusi Oluwole Oladipo. "Banking Sector Reforms and Output Growth of Manufacturing Sector in Nigeria (1970-2011)," Journal of Economics and International Finance 7, no. 8, 2015, 183.

4 L. S. Sanusi, "The Nigerian Banking Industry: What Went Wrong and the Way Forward," Delivered at Annual Convocation Ceremony of Bayero University, Kano held on 3, no. 12010. 
financial system affects the lives of millions of Nigerians as bank and other financial institutions' customers. The centrality of the banking industry and the place of customers/consumers as the drivers of the industry make the protection of the banking services, consumers a priority. This is because consumer protection enhances banking quality and that could be reason the Central Bank of Nigeria (CBN) made it part of its reform policies in the banking industry. ${ }^{5}$

The advancement in technology especially in the Information and Communications sector poses a threat to the consumer. Today consumer products and services are more complex. Unlike before, electronic banking services that are technical and difficult to handle (especially in a country such as Nigeria where literacy is low) are numerous. These include internet banking, mobile banking, e-pay, etc. The usage of electronic banking platforms could involve consumer problems, the resolution of which requires expertise or expert knowledge to be favourably resolved. This expert knowledge is essential but out of the reach or perception of the ordinary banking consumer.

To sustain the system and protect stakeholders either as depositors or as customers/consumers ${ }^{6}$ of the financial services, Nigeria has a body of laws in that regards. These laws include the Banking $\mathrm{Act}^{7}$ 1969, the Nigeria Deposit Insurance Corporation Act No. 16, 2006, ${ }^{8}$ Central Bank of Nigeria Act 2007, ${ }^{9}$ the Banks and Other Financial Institutions Act, ${ }^{10}$ the Consumer Protection Council Act 1992, ${ }^{11}$ and a host of other regulations.

In real consumer protection terms, Nigeria has a long legislative history dating back to 1891 when the Lagos Sale of Drugs Act 1891

Ibid. 13

In this paper, the terms "consumer" and "customer" are used interchangeably.

The Banking Act, 1969 Cap. B, Laws of the Federation of Nigeria, 2004.

8 The Nigerian Deposit Insurance Act, 1969, Cap. N, Laws of the Federation of Nigeria, 2004.

9 The Central Bank of Nigeria Act, 2007, Cap. B, Laws of the Federation of Nigeria, 2004.

10 The Banking and Other Financial Institutions Act, Cap. B3, Laws of the Federation of Nigeria, 2004.

11 The Consumer Protection Council Act, 1992, Cap. C25, Laws of the Federation of Nigeria, 2004. 
was passed. Today, consumer protection in the country is organised in such a way that the Consumer Protection Council (hereinafter referred to as the Council) serves as the principal consumer protection agency. The Council was established under the Consumer Protection Council Act. ${ }^{12}$ Several other departments or agencies were created by different laws to complement the principal consumer protection agency in different sectors of the economy. For the banking industry, the above referred legislations are instructive. Specific mention is, however, made of the Central Bank established under the Central Bank Act 2007, as the banking sector regulator. The interest of a bank consumer in the regulatory role of the $\mathrm{CBN}$ is in having honest and service quality, fair treatment, easy and expeditious disposal of his complaints.

Despite the legislative development in the area of consumer protection, the Nigerian banking industry is characterised by consumer exploitations. These include unrealistic and hidden charges, ${ }^{13}$ unjustifiable deductions, and Automatic Teller Machines (ATM) deductions without dispensing cash to the consumer. Furthermore, there is difficult or near absence of response to consumer complaints and reversal of such deductions upon consumers' complaints. One would therefore, be interested to ask whether the CBN has discharged that mandate in view of its acknowledgement of the poor services delivery and other consumer issues prevalent in the banking industry. If yes, to what extent has that role alleviated the sufferings of banking consumers in view of the acknowledged poor service delivery in the industry?

In view of the above, this paper examined the legal and institutional frameworks for consumer protection in the Nigerian banking industry. It contains the analysis of the relevant legal and regulatory structures for the protection of banking consumers in Nigeria.

\section{Conceptual Framework and Review of Literature}

Bank services cover a series of issues from the normal commercial bank services, mortgage financing and other related services such

12 Consumer Protection Council Act, Cap C 25 L.F.N 2004.

13 Sanusi, L. Sanusi. "Banking reform and its impact on the Nigerian economy."CBN Journal of Applied Statistics 2, no. 2, 2012, 13. 
as discount houses. ${ }^{14}$ Scholars from both the marketing and legal perspectives have underscored the need for protecting the bank consumers.

According to Avanish D. Persuad "consumer protection is an equally vital objective regulation." ${ }^{15}$ As for Maxmillian J. B. Hall, his writing is on the benefits of internationalization and deregulation of financial services from the perspective of efficiency. Maxmillian however, cautioned on the need for control and supervision in the banking sector in consumers' interest. ${ }^{16}$

\section{Complaints Handling}

Complaints handling is a key component of consumer rights. ${ }^{17}$ Studies have found that consumers often need positive responses

from businesses. According to Betty and Stephen ${ }^{18}$ what consumers need when they complain to businesses is a positive response much more than just a letter of acknowledging the complaints. According to Marshal and Verhage complaints play a great role in promoting consumer access to justice. Marshal and Verhage added that consumer attitude towards complaints is dependent on many factors. These factors could either be situational or general but the specific situation appears to be stronger. ${ }^{19}$ Scholars like Yavas, Ugur, ZeynepBilgin, and Donald J. Shemwell emphasized the need and importance of providing bank customers with high quality and efficient complaints handling. ${ }^{20}$ Complaints processing has value to

14 Black, Miller, and Posner. "An Approach to the Regulation of Bank Holding Companies."

15 Avinash D Persaud. "How Should We Regulate the Financial System?," in Reinventing Financial Regulation Springer, 2015, pp. 55-75.

16 Maximilian J. B. Hall. "Banking Regulation and Supervision," Books, 1993.

17 Dahiru Jafaru Usman, Nurli Yaacob, and Aspalella A. Rahman. "Scale Development on Consumer Protection and Its Determinants," International Journal of Law and Management 58, no. 4, 2015: In press.

18 Betty J Diener and Stephen A Greyser "Consumer Views of Redress Needs," Journal of Marketing 42, no. 4, 1978, pp. 21-27.

19 Marsha L. Richins and Bronislaw J. Verhage. "Seeking Redress for Consumer Dissatisfaction: The Role of Attitudes and Situational Factors." Journal of Consumer Policy 8, no. 1, 1985, pp. 29-44.

20 Ugur Yavas, Zeynep Bilgin, and Donald J Shemwell. "Service Quality in the Banking Sector in an Emerging Economy: A Consumer Survey." International Journal Of Bank Marketing 15, no. 6, 1997, pp. 217-223. 
the banking consumer. Accordingly, the authors argue it is useful in a competitive industry such as banking.

\section{Consumer Remedies}

Literature also exists on remedies for defective performance of contracts to supply goods or services, product liability, the remedies available to the consumer, attempts to exclude them and the all-important question of how the remedies can be enforced. Special attention was given to extra-legal enforcement. Robert and Geoffrey ${ }^{21}$ focused more on the practical problems and remedies awarded in consumer cases and or issues. Robert and Geoffrey concentrated on the types of problems that usually arise when an individual consumer orders goods and services from a supplier or provider who then proceeds to render defective performance or no performance at all. Malcolm and Shears ${ }^{22}$ focused was on consumers' rights and remedies under private (or civil) law. It is their view that private law remedies do not afford adequate consumer protection but when compared, administrative remedies and criminal law sanctions play a more significant role in consumer protection as a whole than the private law. Cohen ${ }^{23}$ has written extensively on one element of the legal processes relating to consumer protection- the federal remedies imposed for fraudulent and deceptive practices. The preventive remedies considered in the article are establishment of code of conduct, procedure for disclosure of information, and requirement of substitution of claims. It is her view that although the remedies were introduced to eliminate perceived consumer abuses their emergence was on an ad hoc basis.

\section{Financial Literacy and Language}

The literacy of consumers is a vital issue in protecting the financial services of consumers and a lot of literature exists in that regard. Lack of financial literacy according to Collins hinders the consumers' ability in making well-informed decisions. ${ }^{24}$ According

21 Robert Lowe and G F Woodroffe. Woodroffe \& Lowe's Consumer Law and Practice. Sweet \& Maxwell, 2007.

22 Leder M. and Shrears P., Consumer Law, ed. Pitman Publishing, London, 1999.

23 Dorothy Cohen. "Remedies for Consumer Protection: Prevention, Restitution, or Punishment." The Journal of Marketing, 1975, pp. 24-31.

24 J Michael Collins. "Financial Advice : A Substitute for Financial Literacy ?." Financial Services Review 21, 2012, pp. 307-322. 
to Lusardi while it could be argued that consumers are in charge of their financial security many consumers are not well equipped in making sound financial decisions. ${ }^{25}$ Sandra and Welch reported a low appreciation of financial concepts among financial consumers in the United States of America. ${ }^{26}$ Lack of financial literacy according to Herbert led many people to lose their hard-earned savings and properties. ${ }^{27}$ Herbert argues that consumers are always financial amateurs and that things would have been different and many affected people protected had they got the requisite financial literacy.

According to Lisa, ${ }^{28}$ information and communication technology (ICT) is an important tool in raising the financial literacy of the banking consumers. But the need for financial literacy is further underscored by scholars in view of the development in ICT. Sandra and $\mathrm{Welch}^{29}$ found that the need for financial literacy in recent years has increased due largely to technological advancement and the changes in market and legislation. According to the duo, these changes and advancements made the financial services industry more complex and challenging to the consumers. It therefore, requires more consumer financial literacy and caution in all their financial transactions. Sandra and Welch further found that across the financial services industry considerable resources have been committed towards consumer awareness and even training on consumer financial literacy by several stakeholders in the financial industry. Overall, Sandra and Welch argue that financial literacy training is very vital in shaping consumer decisions.

25 Annamaria Lusardi. "Financial Literacy: An Essential Tool for Informed Consumer Choice?." NBER WORKING PAPER SERIES FINANCIAL 1, no. Working Paper 14084, 2008, pp. 1-29.

26 Sandra Braunstein and Carolyn Welch. "Financial Literacy: An Overview of Practice, Research, and Policy." Federal Reserve Bulletin 88, no. 11, 2002, pp. 445.

27 Herbert Jack Rotfeld. "Financial Aliteracy." Journal of Consumer Affairs, 2008.

28 Lisa J. Servon and Robert Kaestner. "Consumer Financial Literacy and the Impact of Online Banking on the Financial Behavior of Lower-Income Bank Customers." Journal of Consumer Affairs 42, no. 2, 2008, pp. 271-305.

29 Sandra Braunstein and Carolyn Welch. "Financial Literacy: An Overview of Practice, Research, and Policy." Federal Reserve Bulletin 88, no. 11, 2002, pp. 445. 
Understanding concepts relating to financial literacy differs from one place to another. Cultural and national differences have been reported in studies in Canada, Italy, UK and the United States. ${ }^{30}$ The authors therefore, called on policy-makers to always consider the identified differences in developing financial literacy tools. ${ }^{31}$

One related but pressing issue to consumer literacy is the language of the banking industry in Nigeria. The language of all forms, documents and consumer platforms such as bank websites, ATMs and all banking-related forums are in English. Non-English speaking banking consumers in Nigeria deserve protection. Language issue has been captured in consumer protection. Arguing on the rights of non- English speaking consumers, Steven Bender maintains that they are equally entitled to consumer protection like their counterparts who are English literate. ${ }^{32}$

\section{Methodology}

The methodology adopted by this paper was doctrinal legal methodology. The methods of doctrinal research are characterised by the study of legal texts and for this reason, it is often described colloquially as black- letter law. The doctrinal methodology, being rigorous, evaluative and critical, is capable of achieving the objectives of this paper. ${ }^{33}$ Doctrinal methodology is suitable for legal research that involves analysis of legal materials. The methodology facilitated the analysis of the relevant banking legislations in Nigeria.

\section{THE LEGAL AND REGULATORY FRAMEWORK FOR BANKING CONSUMER PROTECTION IN NIGERIA}

Consumer Protection legislation is quite rich particularly in the area of regulated products supplied to consumers. This is because

\footnotetext{
30 Gianni Nicolini, Brenda J. Cude, and Swarn Chatterjee. "Financial Literacy: A Comparative Study across Four Countries." International Journal of Consumer Studies 37, no. 6, 2013, pp. 689-705. Ibid.

32 S.W. Bender. "Consumer Protection for Latinos: Overcoming Language Fraud and English Only in the Marketplace," Am. UL Rev. 1995, pp. 1027-1110..

33 Mahda Zahraaa. Reseach Methods for Law Postgraduate Oversees Students. Stiglow, Kuala Lumpur, 1998.
} 
apart from international legislation on the subject matter, such as the United Nations Guidelines on consumer protection, quite a number of domestic legislation covering the area, i.e. Consumer Protection exist. These legislation comprise the Standard Organisation of Nigerian Act 1971; ${ }^{34}$ the Weight and Measures Act 1974, ${ }^{35}$ the Price Control Act 1977, the National Agency for Food Drugs Administration and Control Act $1993^{36}$, the Nigerian Communications Commissions $\mathrm{Act}^{37}$, the Counterfeit and Fake Drug and Unwholesome processed foods (Miscellaneous offences)Act $1999^{38}$, the Electric Power Sector Reform Act, ${ }^{39}$ the National Insurance Commission Act, the Lotteries Commission Act, the Sales of Goods Edicts/Laws of some states; The Criminal Code Act and the Penal Code Act, the Federal Provision Act, and the Consumer Protection Council Act 1999. As this study was on consumer protection in the banking industry, the paper only examined in detail provisions of the CPC Act, and the provisions of the CBN Act, the Banking Act, and the Bank and other Financial Institutions Acts that had direct bearing on consumer protection.

\section{Consumer Protection Council Act 1992}

The Consumer Protection Council Act 1992, is a landmark in the history of socio-economic legislation in Nigeria. The Act was enacted as a direct rejoinder to the UN Guidelines for Consumer Protection and provides for redress and compensation to consumers' physical safety and health, consumers' economic interest, information and

34 Cap. S9 LFN,2004.

35 EE Tom. "Consumer Rights, Consumer Protection and Public Policy in Nigeria: A Critical Review." International Business Research, 2014, accessed October 27, 2015, http://www.ccsenet.org/journal/index.php/ibr/article/view/42610. Cap W3 LFN 2004

36 Ibid.

37 AB OWOLABI. "Consumer Psychology, Consumer Right and Public Policy in a Nation without Standard." iosrjournals.org (n.d.), accessed October 28, 2015.Shankyula Tersoo Samuel Adedeji Adekunle, ed., Law And Principles of Consumer Protection, First. (Lagos: Nigerian Institute of Advance Legal Studies, 2013).Act No.19 2003.

38 AB OWOLABI. "Consumer Psychology, Consumer Right and Public Policy in a Nation without Standard," iosrjournals.org (n.d.)

39 Dupe Atoki. "CPC Decries High Rate of Consumer Rights Abuse - The Nation Nigeria," accessed November 3, 2015, http://thenationonlineng.net/cpcdecries-high-rate-of-consumer-rights-abuse/. 
education, and the encouragement of voluntary consumer groups ${ }^{40}$ It is likely that achieving the Council's mandate in the above areas will help curtail unwarranted practices which are injurious to the safety and the economic interests of consumers by ensuring that manufacturers, distributors and others involved in the provision of goods and services stick to established laws and necessary guidelines. $^{41}$

In addition to the above, it is part of the Council's mandate to supervise and check undesirable practices such as the adulteration of products, false or misleading claims promotion and services. ${ }^{42}$ One of the fundamental objectives of the law is to provide for better protection of the consumers unlike other existing laws that are punitive or preventive. ${ }^{43}$ Again, the Act intends to provide a less cumbersome, prompt and inexpensive redress to consumers' grievances. It equally protects consumers' interests against inadequacies, fraud and defects in goods and services. ${ }^{44}$

The Consumer Protection Council Act established the Consumer Protection Council and conferred on it the mandate of protecting consumers of goods and services. This law began by establishing a Council consisting of the following:

a) A chairman appointed by the president commander-in-chief of the armed forces on the recommendations of the minister.

b) A person to represent each of the states of the federation on the recommendation of the governor of each states; and

c) Four persons to represent the following related ministries:

i) commerce

ii) industry and technology

iii) health

iv) petroleum resources ${ }^{45}$

Adedeji Adekunle. Law And Principles of Consumer Protection.

Ibid.

42 KB Bello, JBA Suleiman, and I Danjuma. "Perspectives on Consumerism and Consumer Protection Act in Nigeria." European Journal of Business and ... 2012, accessed October 27, 2015.

43 EE Ekanem. "Institutional Framework for Consumers' Protection in Nigeria," International J Advanced Legal Studies and ... 2011.

44 Ibid.

45 CPC, Act Cap. C25 LFN S.1 (2) A,B,\&C. 
d) The tenure of the Chairman and members of the Council other than the ex-officio members was 3 years though renewable for another 3-year period." ${ }^{46}$

Additionally, the president could remove any member other than the ex-officio members. The removal can be from the President or by the recommendation of the Council.

\section{Function of the Council}

For better understanding, it is important to highlight the basic functions of the Consumer Protection Council. According to the $\mathrm{CPC}$ Act, the Consumer Protection Council is to provide speedy redress to consumer complaints through the; removal or elimination of hazardous products from the market; publication from time to time lists of products whose consumption and sale have been banned, withdrawn, severally restricted or not approved by the federal government or foreign governments; compelling the offending company, trade, association or individual to protect, compensate, provide relief and safeguards to injured consumers or communities from the adverse effects of technologies that are inherent harmful, injurious, violent or highly hazardous and increasing public consumer awareness among other functions. ${ }^{47}$

Furthermore, the Council is not established in every state of the federation. However, the Council under the provisions of the Act, is to be assisted by State Committees (hereinafter the Committee) in the execution of its functions. The Committee is to perform its duties under the supervision of the Council. The Committee is to receive, investigate and act on the complaints from consumers in their respective states. The composition of the state committees includes:

a) The nomination of three members to the committee by the governor, one of them shall serve as the chairman of the committee and the remaining two should serve as members; and

b) The appointment appoint of the remaining two by the minister, one of whom shall be a professional.

$46 \quad$ Ibid,S.1(3).

47 Ibid, S.2 A-K. 
It should be noted that the minister by the Act has the right to appoint an officer to serve as the secretary of the state committees. He can be a member of the staff including staff on secondment or transfer from any public service in Nigeria as the minister thinks fit. The Minister also reserves the right to remove any member of the Committee.

"The state committee shall, subject to the control of the Council, have the power to:

a) Receive inquiry into the causes and circumstances of inquiry, loss or damage suffered or caused by a company, trade, association or individual;

b) Negotiate with the parties concerned and endeavour to bring about a settlement; and

c) Where appropriate, recommend to the Council payment of compensation by the offending person to the injured consumer." ${ }^{48}$

Additionally, an individual's or a community's complaints or loss or injury suffered as a result of the use or impact of any goods or services may be filed in writing to seek redress through the Committee. In addition to this, the CPC is not presumed to know the individual's complaints until they are communicated. In this regard the consumer has the duty to make complaints. Section 6 (1) states that "a consumer or a community that has suffered a loss, injury or damage as a result of the use or impact of any goods, product or services may make a complaint in writing to seek redress through a state committee".

Moreover, the CPC Act has identified and takes care of the problem of the inability of persons to write a complaint. Section 6(2) provides for assistance from the clerk or other officials of the Committee for a consumer is or a person's statement to be written without payment of any fee. This will surely encourage illiterate banking consumers in lodging their complaints to the CPC.

Another teething problem that arises from the establishment of the Committees is the difficulty of accessibility to many consumers in the state. The Committee consists of only five members, residing in the state capital. This makes it difficult, if not impossible, for the

48 Ibid, Section 5. 
consumers in the remote areas to easily access the state committee to lodge their complaints. This also necessitates the CPC to expand its functionality to cover such remote areas in order to get closer to the local consumers there.

\section{Consumer Protection Council}

The Consumer Protection Council (the Council) was established by Act No. 66 of $1992^{49}$ to provide holistic protection to Nigerian consumers in line with the United Nations Guidelines for Consumer Protection of 1985. The Council is an agency of the Federal Government of Nigeria, overseen by the Federal Ministry of Trade and Investment. ${ }^{50}$ It is the highest body charged with the responsibility of protecting consumers by the government. Even though the Council was established by an Act in 1992, its operation started in 1999, after its institutional framework was inaugurated. ${ }^{51}$ This was among the major steps taken in giving the consumers' confidence and hope in redressing their grievances against manufacturers and providers of services. ${ }^{52}$ Through the above enabling Act, and as seen above, the CPC has elaborate functions and powers spelt out ranging from speedy redress to consumer complaints through the Alternative Dispute Resolution. It also has mechanisms like mediation, negotiation and reconciliation.

In spite of this set up to ensure consumers are well protected, Nigerian consumers are among the most exploited in the whole world. ${ }^{53}$ In the banking sector, unresolved consumers' complaints and poor handling mechanisms as well as excess charges from commercial

49 Muhammed Tawfiq Ladan. "The Limits of Legal and Enforcement/ Regulatory Frameworks in Consumer Protection Against Counterfeit and Pirated Products: The Nigerian Experience," NLIPW 1, no. 2, 2013.

50 "Consumer Protection Council in 18,Ilupeju By-Pass, Ilupeju, Mushin, Lagos, Nigeria | VConnect ${ }^{\mathrm{TM}}$," accessed November 1, 2015, http://www.vconnect. com/consumer-protection-council-mushin-lagos_b142587

51 "Consumer Protection Council (Abuja) at Wuse, Abuja | Connect Nigeria. com," accessed November 5, 2015, http:/www.connectnigeria.com/businesses/ consumer-protection-council-abuja-31340.html

52 Ekanem. "Institutional Framework for Consumers' Protection in Nigeria."

53 "Consumer Protection in Nigeria| The Lawyers Chronicle," accessed October 28, 2015, http://thelawyerschronicle.com/consumer-protection-in-nigeria/ 
banks ${ }^{54}$ are the order of the day. Many consumer complaints take longer time than necessary to be resolved. In fact, some complaints are never resolved at all.

The Consumer Protection Council being the regulatory agency has on certain occasions come up with pro-consumer initiatives aimed at driving unprecedented and positive changes in certain sectors of the economy. On several occasions, the Council came up with different initiatives targeted at bringing relief to the consumers on issues such as Automated Teller Machine (ATM) anomalies, poor telecom services delivery, lack of refund policy for defective ICT devices, as well as a wide range of abuses from ICT enabled services/products. ${ }^{55}$

\section{The Banking Act 1969}

The first banking legislation in Nigeria was the Banking Ordinance $1952^{56}$ which came into existence following the recommendations of Paton's report. One of the main reasons that necessitated this Committee's report was the absence of regulations, measures for the establishment, maintenance and control of banks at the time. The government was already aware of the need to establish a sort of "Code of Conduct" for the banking industry. This Ordinance paved way for the regulations and licensing of the banking activities in Nigeria. Prior to this, banking activities were left unchecked to the extent that anyone could start a banking business with a small capital or no capital at all.

In 1958, a new banking Act was promulgated and later amended in 1962 to accommodate more growth in the banking industry. The Banking Act 1969 in some of its provisions provided protection to the banking consumers. Some of these provisions included Sections 1,13 and 21. The analysis of the contents of these Sections is provided below.

54 Olumuyiwa Ojoawo "Consumer Protection: CBN Recovers N9bn Excess Charges from Banks | TheCitizen - Nigeria's Leading Online Newspaper." accessed November 3, 2015.

55 "Nigeria: CPC Introduces Measures Against Abuses in ICT - allAfrica.com," accessed November 5, 2015, http://allafrica.com/stories/200912160133.html

56 Banking Ordinance No.15 of 1952. 
Section 1 of the Banking Act 1969 provides that no banking activity can be transacted in Nigeria except by a company duly incorporated and one that has obtained a valid licence endorsed by the Commissioner of Finance. In the same vein the licence is issued based on the recommendations of the $\mathrm{CBN}$ and may be revoked, varied or imposed additional conditions when the bank in question contravenes the law. The requirement of the license before setting up a bank and the monitoring the powers conferred by the CBN was a step towards the protection of the consumer. Prior to the 1952 Banking Ordinance, the above provision did not exist. Undoubtedly this provision accords protection to the banking consumer/customer. It further gives encouragement, and guarantees under the law, that consumers' deposits will be safe and this avoids many uncertainties which had happened to a number of creditors prior to 1952 in Nigeria when a significant number of banks was collapsing day by day. ${ }^{57}$

Section 13 of the Act provides restrictions in granting advance loans or credit facility. It forbids any Bank licensed under the Act from granting advance loan, credit facility or bank guarantee to any person, where the total exceeds $33 \%$ of the paid up capital and statutory reserve of the bank. The section orders that loans and credit facilities are to be approved and granted in accordance with the laid down rules and regulations. It goes further to say that where such rules and regulations involve the deposit of collateral security prior to the granting of loan, such security shall be deposited with the bank. In addition to this, unprotected loans above N1, 000 cannot be granted either to its director or any other company, especially one in which bank directors are interested. The Act, curtailing the powers of the commercial banks in granting unsecured loans is yet another effort to protect the rights and interests of the banking consumer.

Section 21 of the Act empowers the CBN to appoint a chief examiner among its staff and charges him with the responsibility of examining periodically, and under state of privacy, the books of account in particular and affairs of each bank in general. In certain circumstances, the Finance Commissioner may order a special examination after consultations with the $\mathrm{CBN}$. Where it is established that a bank has insufficient money to cover its liability or conducts its business in a way injurious to the interest of the consumer/customer

57 D. Alford. "Nigerian Banking Reform: Recent Actions and Future Prospects," Available at SSRN 1592599, 2010. 
and other creditors, the Commissioner may require such a bank to rectify the situation by convening a meeting with the directors of the bank concerned or summon any official of the concerned bank to discuss the various issues troubling the concerned bank. The Commissioner can also order the bank to change its management. The Commissioner can also nominate and recommend to the bank an experienced person to advise on the best and appropriate ways of conducting the business of the concerned bank.

It is vital to note that the above provisions demonstrate control over the commercial banks under the Banking Act 1969. Certainly, these provisions have been favourable to the banking consumers. The latest wide-ranging legislation on banking is contained in the Banking Decree No.1 of $7^{\text {th }}$ February 1969 as amended by the Banking Decree No.30 of 1970 and the Banking Decree No. 45 of 1972. It is however, worthy to note that the Banking Act 1969 and all its amendments were repealed by the BOFIA.

\section{Central Bank of Nigeria Act 2007}

One of the most important institutional changes in the history of monetary and financial system in Nigeria happened in 1958 with the establishment of the Central Bank. ${ }^{58}$ As discussed above, the banking industry was without regulation and control. As such, in 1948, a panel of inquiry was established by the British colonial government under the leadership of Mr G.D. Paton to examine banking activities in the country. This followed the series of collapse of many indigenous banks in the 1940s, which ruined their depositors. The panel sat, deliberated and forwarded its report which became the basis of the first banking legislation in Nigeriathe Banking Ordinance of 1952. In 1958 a bill for the establishment of CBN was presented to the House of Representatives. The Act was passed into law on $1^{\text {st }}$ July, 1959, after the CBN came into force. The CBN Act was further promulgated in 1991 by Decree No. 24 by the Military Government. ${ }^{59}$

58 K.I.Igweike, Law of Banking and Negotiable Instruments, onitsha. Africana first publishers limited, 2005.

59 KG Muhammad. "A Critical Analysis of the Conformity of Extant Banking and Related Laws with Electronic Banking in Nigeria." Journal of Law, Policy and Globalization (2015), accessed November 5, 2015, http://www.iiste.org/ Journals/index.php/JLPG/article/view/20331 
In addition to the above, in 1997, the government of Nigeria enacted the CBN (Amendment) Decree No.3 and BOFI (Amendment) Decree No.4 to totally remove the restricted autonomy which the banks enjoyed since 1991. Moreover, the CBN (Amendment) Decree No.37 of $1997 . .^{60}$ The CBN (Amendment) Decree No.37 of 1998 repealed the CBN (Amendment) Decree No.3 of 1997. The CBN Act was further re-enacted and commenced work on 25 May 2007 and it contains 61 sections. Similarly, CBN is regarded by the Act as a corporate body with perpetual succession and a common seal capable of suing and sue in its own corporate name. ${ }^{61}$ It is the apex law responsible for regulating banks and other financial institutional activities in Nigeria. ${ }^{62}$

It is interesting to note that throughout the 61 sections of the Act, there is no single section that directly accords protection to the banking consumers. The only section closer to the ideals of consumer protection is Section 2 of the CBN Act. Section 60 explains the entrenchment of the sound financial system as part of the rationale for establishing the CBN. A sound financial system is in the banking consumers' interests. It is of equal importance to note that the Act is responsible for implementing and administering the provisions of BOFIA, which aims at ensuring high standards of banking practice and financial stability through its surveillance activities of which banking consumer protection is part of. This is because consumer protection enhances banking quality. ${ }^{63}$ In order to cover the above gap, and avoid other banking consumer right violations ${ }^{64} \mathrm{CBN}$ in 2010 created the Consumer Protection Unit that in 2012 attained the status of Department. This department deals with issues relating to consumers' complaints regarding their dealings with banks, and enhances consumer financial capability through consumer education, ensuring fair and responsible markets and business conduct amongst financial service providers.

\footnotetext{
60 Ibid.

${ }^{61}$ Section 2 CBN Act 2007.

62 Oserheimen A. Osunbor, The Bank Director and the Law, Second. Lagos, FITC Publishers, 2007. p. 10

63 Sanusi. "The Nigerian Banking Industry: What Went Wrong and the Way Forward."

64 "CBN Threatens to Sanction Banks over Customers' Complaints on Excess Charges Premium Times Nigeria,"
} 


\section{Bank and Other Financial Institutions Act (BOFIA) 1991}

The government's control over the activities of banks and other financial institutions was strengthened by the promulgation of the Banking (Amendment) Act of 1962. This enactment in various areas attempted to remove the ambiguities and loopholes in the original formulation of the previous banking statutes such as the Banking Ordinance of 1958 (Cap.19). The 1962 Act also added the powers of the CBN on monetary control. The enactment of the Companies Decree No 51 of 1968 made it compulsory for all companies including banks operating to be incorporated in Nigeria.

It should be remembered that, all the above enactments which relate to banking operations were further codified in the Banking Decree No 1 of 1969. The promulgation of the Nigerian Enterprises Promotion Decree of 1972 to 1977, which was repealed in 1989, concluded a host of banking and other institutions' legislation that had far reaching effects on the operations of the banking industry over 10 years. After more than a decade and a half of banking legislation, a more comprehensive legislative framework for banking operation was conceived and executed in the name of Banks and Other Financial Institutions Decree No. 25 of 1991(BOFID) which was to augment regulation and supervise effective monetary policy. The promulgation of BOFID in 1991 was for banking and non-banking institutions in the country. ${ }^{65}$

The BOFIA is a codification of all the pre 1991 banking laws and was enacted to fill in the obvious lacunae created by the CBN Act. This gap range from advertisement for deposits, interest charging or lending to grounds for the revocation of licenses. The underlying philosophy is to protect the banking consumer. It empowers the governor of the $\mathrm{CBN}$ to remove any staff or manager of a failing bank or other financial institution. BOFIA is the present operational law in this regard. The Act contains sixty-seven (67) sections. A careful perusal of some of the Sections reveals that they accorded consumers of the banking industry some protection. While others need to be further amended in order to take care of banking consumer protection.

Muhammad. "A Critical Analysis of the Conformity of Extant Banking and Related Laws with Electronic Banking in Nigeria." 
Section 13(1) states:

A bank shall maintain at all times capital funds unimpaired by losses; in such ratio to all or any assets or to all or any liability of the bank and all its offices in and outside Nigeria as may be specified by the Bank. ${ }^{66}$

(2) Any bank which fails to observe any specified ratio may be prohibited by the Bank from:

a) Advertising for or taking new deposits;

b) Granting credit and making investments;

c) Paying cash dividends to share holders

(3) In addition, the Bank (CBN) may be required to draw up within a specified time a capital reconstitution plan acceptable to the Bank." ${ }^{967}$

The weight of the above provision is that, when a bank cannot meet its obligations, its license shall be revoked by the Governor of CBN. Circumstances where a bank may not meet its obligation abound. The most common is where the bank is unable to meet its responsibility to pay consumers their deposited funds. With regards to this, section 16 states that a reserve fund of not less than $30 \%$ of its net profits must be earmarked by the bank. This fund may in appropriate cases, be used to settle the banking obligations to its customers/consumers.

Section 23(1) of the Act states: "Every bank shall display at its offices its lending and deposit interest rates and shall render to the Bank (CBN) information on such rates as may be specified from time to time by the Bank" ${ }^{\prime \prime 8}$ The issue of displaying lending and deposit interest rates of a bank should not be limited to the bank offices alone, but rather the rates should also be sent through e-mail or SMS to every banking consumer dealing with the bank, as this will serve as a way of educating banking consumers and will equally reduce excess/unreasonable charges.

66 Bofia Section 13 LFN 2004.

67 Ibid.

68 Section 23 Bofia LFN 2004. 
Section 24 of the Act deals with the issue of keeping of books of account by banks. The subsection states thus: "The books of account shall be kept at the principal administrative office of a bank and at the branches of each bank in the English language or any other language approved by the Federal Government." ${ }^{\prime 9}$

This subsection of the Act acknowledges the use of other native languages in preparing books of account subject to the approval of the Federal Government. This subsection needs to be amended to clearly include the three major languages while preparing books of account, i.e. Hausa, Yoruba and Ibo. Including native languages will surely enhance better understanding and the financial literacy of banking consumers.

Section 33 (b) provides that the CBN may give an order for special examination or investigation of the books of affairs of a bank where it is satisfied that the bank is conducting its business in the manner detrimental to the interest of the banking consumer.

Section 44 (3) states that where any commercial bank intends to issue any advertisement, the bank shall deliver to the CBN the text of the proposed advertisement together with the bank's latest published accounts as the $\mathrm{CBN}$ may prescribe and such text may be considered as confidential information. ${ }^{70}$

It is imperative to note the rationale behind the restriction on advertisement for deposit is to protect banking consumers against fraud or any misleading information that may arise in the cause of such advertisement. Subsection 4 makes it an offence liable to a fine of $\mathrm{N} 50,000$ and in addition, another fine of $\mathrm{N1}, 000$ for every day during which an advertisement issue remains in contravention of subsection 3 of this Section. Here the issue of $\$ 50,000$ needs to be reviewed to $\$ 100,000$ and $\$ 1,000$ also be increased to $\$ 5,000$ in order to meet the current economic situation.

Section 48 of this Act $^{71}$ asserts some disqualification and exclusion of certain individuals from being part of the management of banks based on the reason of unsound mind, resulting in incapability of

\footnotetext{
69 Section 24Bofia LFN 2004.

70 Section 43 Bofia LFN 2004.

71 Bofia LFN 2004.
} 
carrying out their duties, or, where an individual is declared bankrupt or where he refuses to make payment to his creditors, or is convicted by court on an offence involving fraud or dishonesty or where he is disqualified to practice his profession. All these are to safeguard and protect the consumers and to an extent bank depositors.

In addition to the above, no person can be a director or part of the management of any bank where he happened to be a director before, in a bank which has been wound up by the Federal High Court with express authority of the governor of the Central Bank. The essence of this exclusion is to restrict people with tainted character or legal incapacity from dealing in any way with the investments of banking consumers.

\section{An analysis of the Legal Regime}

From the above, it is glaring that the Central Bank Act which is the main banking industry law lacks a section that clearly and directly talks of consumer protection. The closest is Section 2 that calls for the entrenchment of the sound financial system as one of the objectives for establishing the Central Bank of Nigeria. Other issues though not direct could be termed to have consumer protection dimension. Provisions of Section 24, providing an opening for the publication of books of accounts of banks in any language other than the English language, have consumer awareness dimensions because not all the banking consumers are literate in the English language. Unfortunately, the Federal Government is yet to direct the publication of books of account in any native language. FINDOUT FOR MALAYSIA is a paper that recommends the inclusion in the CBN Act of clear and precise consumer protection provisions. This is important because the current standing of the consumer under the said legislation is near non-existent.

From the analysis of the Central Bank Act in particular, it appears that no provision exists for consumer redress. This is a flaw. Redressing consumer complaints is key in the consumer protection systems. There is equally a lack of any rule or regulation in the banking industry mandating the resolution of consumer complaints on time. In fact, only in 2010 did the Central Bank establish a consumer protection unit despite consumer sufferings in the industry. In view 
of this, this research recommends the Central Bank of Nigeria to draw up guidelines or regulations that clearly state the duration the dispute resolution process should take in the banking industry. The issue of the time limit at the level of the banks and when a consumer can approach the apex bank should be stated. This will improve the efficiency of complaint processing in the Nigerian banking industry. Violation of the guidelines should be met with adequate sanctions from the apex bank.

\section{CONCLUSION}

This paper examined the legal regime on banking regulations and consumer protection. It highlighted the banking sector regulatory laws and revealed what protection, if any, is provided in the said laws and the institutional arrangements in that regards. The highest and all purpose (good and services) consumer protection legislation, the Consumer Protection Council Act, was thoroughly examined. The analysis reveals that the banking laws and the regulatory institutions provide inadequate protection to the banking consumer. This is a cause for the concerns of the banking consumers in the country. This state of things could be considered as the contributory fact for growing consumer rights abuses and humiliation in the Nigerian banking industry.

Banking consumers are a force to reckon with in all economies. They deserve to be protected in their dealings with banks. This is the responsibility of both the government and the commercial banks. This is because the government, especially in Nigeria, has a duty to ensure that economic exchanges are in the best ethical ways between the bank and its customers who are undoubtedly the weakest party in resources and power terms when compared with the commercial banks. In Nigeria, the research found that the government in a bid to discharge the responsibility imposed on it had, beginning from the Banking Act, the Consumer Protection Act, Central Bank of Nigeria Act and most recently the Banks and Other Financial Institutions Act, made provisions for the regulation of the banking industry and to some extent consumer protection. Notwithstanding these cited laws the research found that the legal regime is inadequate to offer the needed protection to the Nigerian Banking consumers. No concrete provisions are made in the Central Bank of Nigeria Act. 
Consumers' rights as well as the complaint processing structures are neither mentioned nor spelt out. The paper argues therefore, that consumer rights violations and concerns are daily issues in Nigeria despite all these laws and the institutions such as the Central Bank of Nigeria. This is attributable to gaps and lapses that have been identified in the laws from both the legal and institutional angles. Thus, this paper argues banking consumers need protection and this can be done through the improvement of the legal and institutional structures for their protection.

\section{BIBLIOGRAPHY}

AB OWOLABI. Consumer Psychology, Consumer Right and Public Policy in a Nation without Standard. iosrjournals.org (n.d.)

AB OWOLABI. Consumer Psychology, Consumer Right and Public Policy in a Nation without Standard, iosrjournals.org (n.d.)

Adedeji Adekunle (n.d.). Law and Principles of Consumer Protection. Banking Ordinance No.15 of 1952.

Betty, J. D., \& Stephen, A. G. (1978). Consumer views of redress needs. Journal of Marketing, 42(4), 21-27

Black, F., Merton, H. M., \& Richard, A. P. (1978). An approach to the regulation of bank holding companies, Journal of Business (July), 379-412.

Bofia LFN 2004.

Bofia Section 13 LFN 2004.

Braunstein, S., \& Welch, C. (2002). Financial literacy: An overview of practice. Research and policy. Federal Reserve Bulletin, 88(11), 445-457.

Cap. S9 LFN, 2004.

CBN Threatens to Sanction Banks over Customers' Complaints on Excess Charges Premium Times Nigeria.

Cohen, D. (1975). Remedies for consumer protection: Prevention, restitution, or punishment. The Journal of Marketing, 39(4), 24-31.

Collins, J. M. (2012). Financial advice: A substitute for financial literacy? Financial services review, 21(4), 307-322.

Consumer Protection Council (Abuja) at Wuse, Abuja | ConnectNigeria.com. Retrieved from http://www. connectnigeria.com/businesses/consumer-protectioncouncil-abuja-31340.html 
Consumer Protection Council Act, Cap C 25 L.F.N 2004.

Consumer Protection Council in 18, Ilupeju By-Pass, Ilupeju, Mushin, Lagos, Nigeria | VConnectTM." accessed November 1,2015, http://www.vconnect.com/consumer-protection-councilmushin-lagos_b142587

Consumer Protection in Nigeria | The Lawyers Chronicle. Retrieved from http://thelawyerschronicle.com/consumer-protectionin-nigeria/

CPC, Act Cap. C25 LFN S.1 (2) A, B, \& C.

D. Alford. Nigerian Banking Reform: Recent Actions and Future Prospects. Available at SSRN 1592599, 2010.

Dahiru Jafaru Usman, Nurli Yaacob, \& Aspalella A. Rahman. (2015). Scale development on consumer protection and its determinants. International Journal of Law and Management, 58(4). In press.

Dupe Atoki. CPC Decries High Rate of Consumer Rights Abuse The Nation Nigeria. Retrieved from http://thenationonlineng. net/cpc-decries-high-rate-of-consumer-rights-abuse/.

E. Ekanem. (2011). Institutional Framework for Consumer Protection in Nigeria. International Journal of Advanced Legal Studies and. Governance, 2(1).

EE Tom. Consumer Rights, Consumer Protection and Public Policy in Nigeria: A Critical Review. International Business Research, 2014. Retrieved from http://www.ccsenet.org/ journal/index.php/ibr/article/view/42610.Cap W3 LFN 2004

Ekanem. Institutional Framework for Consumers' Protection in Nigeria.

Fischer B., Merton, H. M., \& Richard, A. P. (1978). An approach to the regulation of bank holding companies, The Journal of Business, 51(3), 379-412.

In this paper, the terms "consumer" and "customer" are used interchangeably.

K.I.Igweike, Law of Banking and Negotiable Instruments, Onitsha. Africana first publishers limited, 2005.

KB Bello, JBA Suleiman, and I Danjuma. Perspectives on Consumerism and Consumer Protection Act in Nigeria. European Journal of Business and ... 2012.

KG Muhammad. (2015). "A Critical Analysis of the Conformity of Extant Banking and Related Laws with Electronic Banking in 
Nigeria." Journal of Law, Policy and Globalization accessed November 5, 2015, http://www.iiste.org/Journals/index.php/ JLPG/article/view/20331

Leder, M., \& Shears, P. (1996). Consumer Law. (4th edn). Great Britain: Financial Times Pitman Publishing.

Lusardi, A. (2008). Financial Literacy: An Essential Tool for Informed Consumer Choice? NBER. Working paper 14084. $1-29$.

Mahda Zahraaa. (1998). Research methods for law postgraduate oversees students. Kuala Lumpur: Stiglow.

Mark E. Budnitz.(1995). Arbitration of Disputes between Consumers and Financial Institutions: A Serious Threat to Consumer Protection, 10 Ohio St. J. Disp. Resol. 267.

Marsha, L. R., \& Bronislaw, J. V. (1985). Seeking redress for consumer dissatisfaction: The role of attitudes and situational factors. Journal of Consumer Policy, 8(1), 29-44.

Maximilian Hall. (1993). Banking Regulation and Supervision: A Comparative Study of the UK, USA and Japan.

Muhammad (n.d). A Critical Analysis of the Conformity of Extant Banking and Related Laws with Electronic Banking in Nigeria.

Muhammed Tawfiq Ladan. (2013). The Limits of Legal and Enforcement/ Regulatory Frameworks in Consumer Protection Against Counterfeit and Pirated Products: The Nigerian Experience," NLIPW 1, no. 2.

Nicolini, G., Brenda J. C., \& Swarn Chatterjee. (2013). Financial literacy: A comparative study across four countries. International Journal of Consumer Studies, 37(6), 689-705.

Nigeria: CPC Introduces Measures Against Abuses in ICT - allAfrica.com. Retrieved from http://allafrica.com/ stories/200912160133.html

Olanrewaju, Oluwagbenga Gideon, Aremo, Adeleke Gabriel, \& Aiyegbusi Oluwole Oladipo. (2015). Banking sector reforms and output growth of manufacturing sector in Nigeria (19702011). Journal of Economics and International Finance, 7(8), 183-191

Olumuyiwa Ojoawo. Consumer Protection: CBN Recovers N9bn Excess Charges from Banks. TheCitizen - Nigeria's Leading Online Newspaper. 
Oserheimen A. Osunbor. (2007). The Bank Director and the Law, Second. Lagos, FITC Publishers. p.10

Persaud, A. D. (2015). How Should We Regulate the Financial System? In Reinventing Financial Regulation. Apress, Berkeley, CA.

Robert, L., \& Woodroffe, G. F. (2007). Woodroffe \& Lowe's consumer law and practice. London: Sweet \& Maxwell.

Rotfeld, H. J. (2008). Financial a literacy. Journal of Consumer Affairs, 42(2), 306-309.

Sanusi, L. S. (2010). The Nigerian Banking Industry: What Went Wrong and the Way Forward. Delivered at Annual Convocation Ceremony of Bayero University, Kano.

Sanusi, L. S. (2012). Banking reform and its impact on the Nigerian economy. CBN Journal of Applied Statistics, 2(2), 115-122

Sanusi (n.d.). The Nigerian Banking Industry: What Went Wrong and the Way Forward.

Servon, L. J., \& Robert, K. (2008). Consumer financial literacy and the impact of online banking on the financial behavior of lower-income bank customers. The Journal of Consumer Affairs, 42(2), 271-305.

Shankyula Tersoo Samuel Adedeji Adekunle (ed.) Law and Principles of Consumer Protection, First. (Lagos: Nigerian Institute of Advance Legal Studies, 2013). Act No.19 2003.

Steven, W. B. (1996).Consumer Protection for Latinos: Overcoming Language Fraud and English Only in the Marketplace, 45 AM. U. L.REV. 1027

The Banking Act, 1969 Cap. B, Laws of the Federation of Nigeria, 2004.

The Banking and Other Financial Institutions Act, Cap. B3, Laws of the Federation of Nigeria, 2004.

The Central Bank of Nigeria Act, 2007, Cap. B, Laws of the Federation of Nigeria, 2004.

The Consumer Protection Council Act, 1992, Cap. C25, Laws of the Federation of Nigeria, 2004.

The Nigerian Deposit Insurance Act, 1969, Cap. N, Laws of the Federation of Nigeria, 2004.

Ugur Yavas, Zeynep Bilgin, \& Donald, J. S. (1997). Service quality in the banking sector in an emerging economy: A consumer survey. International Journal of Bank Marketing, 15(6), 217223. 